\title{
Estrogen regulation in human breast cancer cells of new downstream gene targets involved in estrogen metabolism, cell proliferation and cell transformation
}

\author{
J A Vendrell ${ }^{1,2}$, F Magnino ${ }^{1}$, E Danis ${ }^{1}$, M J Duchesne ${ }^{3}$, S Pinloche $^{4}$, M Pons $^{3}$, \\ D Birnbaum ${ }^{5}$, C Nguyen $^{6}$, C Theillet ${ }^{1}$ and P A Cohen ${ }^{1,2}$ \\ ${ }^{1}$ EMI 0229 INSERM, Centre de Recherche CRLC Val d'Aurelle, Montpellier, France \\ ${ }^{2}$ CPBS-CNRS, Centre de Biotechnologie et de Pharmacologie pour la Santé, Faculté de Pharmacie, BP14491, 34093 Montpellier Cedex 5, France \\ ${ }^{3}$ INSERM U439, 70 Rue de Navacelles, Montpellier, France \\ ${ }^{4}$ LIRMM, 161 rue Ada, Montpellier, France \\ ${ }^{5}$ INSERM U119 and LBT, Institut Paoli Calmette, Marseille, France \\ ${ }^{6}$ Laboratoire TAGC, CIML, Université d'Aix-Marseille II, Marseille, France \\ (Requests for offprints should be addressed to P A Cohen, CPBS-CNRS, UMR5160 Centre de Biotechnologie et de Pharmacologie pour la Santé, \\ Faculté de Pharmacie, BP14491, 34093 Montpellier Cedex 5, France; Email: pascale.cohen@ibph.pharma.univ-montp1.fr)
}

\begin{abstract}
We explored, by cDNA mini-arrays, gene expression measurements of MVLN, a human breast carcinoma cell line derived from MCF-7, after 4 days of exposure to $17 \beta$-estradiol $\left(E_{2}\right)$ treatment, in order to extend our understanding of the mechanism of the pharmacological action of estrogens. We focused on 22 genes involved in estrogen metabolism, cell proliferation regulation and cell transformation. The specificity of the $E_{2}$ response was reinforced by comparison with 4-hydroxytamoxifen $(\mathrm{OH}-\mathrm{Tam}), \mathrm{ICI}$ 182,780 and $\mathrm{E}_{2}+\mathrm{OH}$-Tam expression profiles. Real-time quantitative PCR (RTQ-PCR) confirmed the variation of expression of known (TFF1, AREG, IRS1, IGFBP4, PCNA, ERBB2, CTSD, MYC) as well as novel (DLEU2, CCNA2, UGT1A1, ABCC3, ABCC5, TACC1, EFNA1, NOV, CSTA, MMP15, ZNF217) genes. The temporal response of these gene expression regulations was then investigated after 6 and $18 \mathrm{~h}$ of $\mathrm{E}_{2}$ treatment and this allowed the identification of different time-course patterns. Cycloheximide treatment studies indicated first that estrogen affected the transcript levels of $A B C C 3$ and $A B C C 5$ through dissimilar pathways, and secondly that protein synthesis was needed for modulation of the expression of the CCNA2 and TACC1 genes by estrogens. Western blot analysis performed on TFF1, IRS1, IGFBP4, amphiregulin, PCNA, cyclin A2, TACC1 and ABCC5 proteins confirmed the mini-array and RTQ-PCR data, even for genes harboring low variations of mRNA expression. Our findings should enhance the understanding of changes induced by $E_{2}$ on the transcriptional program of human $E_{2}$-responsive cells and permit the identification of new potential diagnostic/prognostic tools for the monitoring of estrogen-related disease conditions such as breast cancer.
\end{abstract}

Journal of Molecular Endocrinology (2004) 32, 397-414

\section{Introduction}

In the reproductive system, estrogens are important regulators of growth and differentiation in the normal mammary gland and participate in the development and progression of breast carcinoma (Pike et al. 1993). The pharmacological effects of the $17 \beta$-estradiol $\left(\mathrm{E}_{2}\right)$ molecule have been mainly attributed to its capacity to modify, directly or indirectly, the expression of key genes. For example, the mitogenic effects of estrogens on breast epithelial cells are, at least in part, the consequence of an increased expression of genes involved in the regulation of the cell cycle (Prall et al. 1997). Direct transcriptional activity of $\mathrm{E}_{2}$ involves the binding to either estrogen receptor 
(ER)- $\alpha$ or ER $\beta$ (Kuiper et al. 1996, Krege et al. 1998, Ogawa et al. 1998). ER $\alpha$ and $\operatorname{ER} \beta$ both recognize as ligand-bound dimers the classical estrogen response element (ERE) (Klein-Hitpass et al. 1988). ER-mediated transcription involves not only ER-DNA binding but also the complex recruitment of transcriptional regulators that influence the interaction between ER and the basal transcription machinery (McKenna et al. 1999). Besides classical interaction with the ERE, ligandactivated ERs also regulate gene expression by interacting directly with the AP-1 protein complex (Webb et al. 1999), the Spl protein (Safe 2001) or the nerve factor- $\mathrm{KB}(\mathrm{NF}-\mathrm{\kappa B})$ protein (Harnish et al. 2000). Finally, besides these so-called genomic actions of estrogens, a non-genomic action is also known (Kousteni et al. 2001).

$\mathrm{ER} \alpha$ is routinely used as a prognostic and predictive marker in the management of breast cancer patients. Compared with ER-negative (ER-) breast tumors, a high percentage of ER-positive $(\mathrm{ER}+)$ tumors respond favorably to endocrine treatment, are associated with better prognosis and have a well-differentiated phenotype (Henry et al. 1988, Pichon et al. 1996). The marked physiological and phenotypic differences between the ER+ and ER- breast tumors may be the consequence of different gene expression profiles. A full understanding of the pharmacological effect of estrogens on downstream gene targets is therefore very important, and large-scale studies of gene expression systems such as cDNA micro-arrays and oligonucleotide chips (Cohen et al. 2000) have been used to identify $\mathrm{E}_{2}$ downstream target genes (Klein-Hitpass et al. 1988, Soulez \& Parker 2001, Inoue et al. 2002, Hodges et al. 2003).

The aim of the present study was to explore, on home-made cDNA mini-arrays, gene expression measurements of MVLN, an ER $\alpha$-positive and hormone-responsive human breast carcinoma cell line derived from one of the standard models of $\mathrm{ER}+$ breast cancer, the MCF-7 cell line (Demirpence et al. 1993). We explored the gene expression measurements of MVLN cells in response to three ligands of $\mathrm{ER}: \mathrm{E}_{2}$, the selective estrogen receptor modulator (SERM) 4-hydroxytamoxifen (OH-Tam) and the pure antagonist ICI 182,780. We searched for genes differentially expressed after $\mathrm{E}_{2}$ treatment to extend our understanding of the mechanisms of the pharmacological action of estrogens, and to select gene candidates as potential diagnostic/prognostic tools of breast cancer. The computed data allowed us to identify new genes whose expression was specifically modulated under $\mathrm{E}_{2}$ treatment and which might encode proteins playing a critical role in hormone-responsive tissues and cancer.

\section{Materials and methods}

\section{Cell culture}

The MVLN cell line was grown as previously described (Demirpence et al. 1993). Prior to treatment, MVLN cells were purged for 5 days in Dulbecco's modified Eagle's medium without phenol red supplemented with 3\% steroid-depleted, dextran-coated charcoal-treated fetal calf serum. Cells were then treated for 4 days (with one medium change) under the following pharmacological conditions: steroid-depleted medium (vehicle), $1 \mathrm{nM} \mathrm{E}$, $200 \mathrm{nM}$ OH-Tam, $100 \mathrm{nM}$ ICI 182,780 , or both $1 \mathrm{nM} \mathrm{E} \mathrm{E}_{2}$ and $200 \mathrm{nM} \mathrm{OH}-\mathrm{Tam}$ (Pons et al. 1990, Demirpence et al. 1993, Badia et al. 2000). Total RNA was extracted by cesium chloride ultracentrifugation, and RNA integrity was checked by denaturing agarose gel electrophoresis.

\section{Culture in the presence of a protein synthesis inhibitor}

Cells were pretreated for $1 \mathrm{~h}$ with cycloheximide (CHX; Sigma-Aldrich, St Quentin Fallavier, France) at $30 \mu \mathrm{g} / \mathrm{ml}$, then $1 \mathrm{nM} \mathrm{E}_{2}$ was added (Cavailles et al. 1989). Cells were then harvested after 6 and $18 \mathrm{~h}$ of treatment before extracting total RNA.

\section{Spotted cDNA arrays}

Variations in gene expression levels were analyzed by large-scale measurement with home-made nylon cDNA mini-arrays $(7 \cdot 5 \times 11.5 \mathrm{~cm} ; 1019$ human genes; 12 genes $\left./ \mathrm{cm}^{2}\right)$ produced in our facility (TAGG laboratory, CIML, University of AixMarseille II, France) as described by Bertucci et al. (1999). Spotted targets were single amplified PCR products amplified from control clones and IMAGE cDNA clones (IMAGE consortium, Hinxton, Cambridgeshire, UK). The human cDNA clones were selected on the basis of practical 


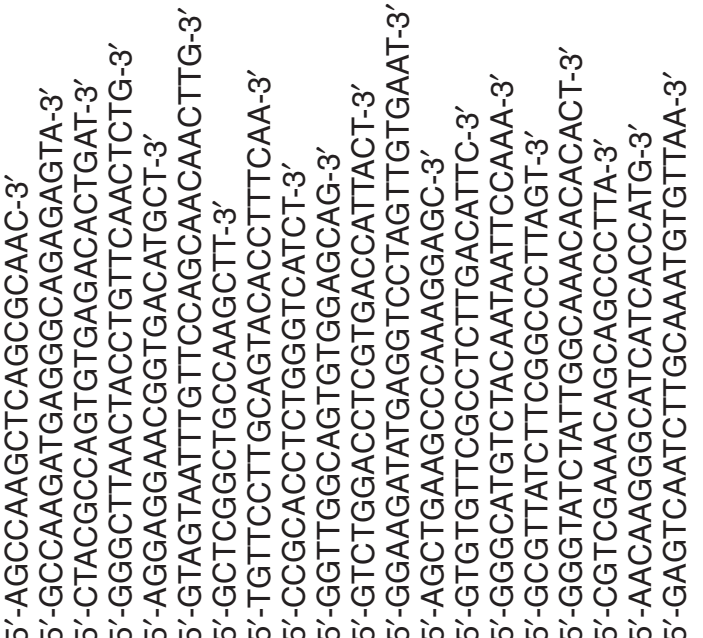

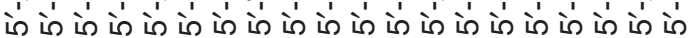

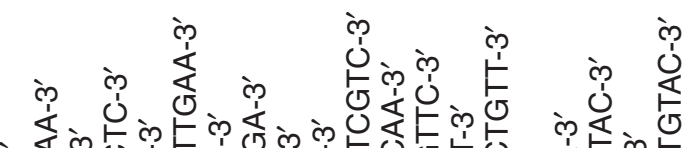
केष के

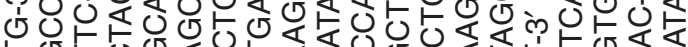

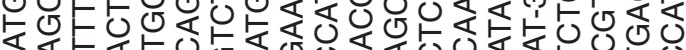

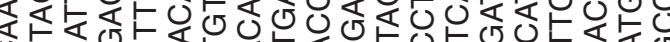

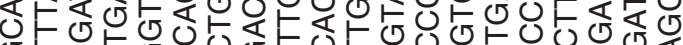

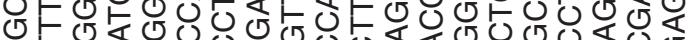

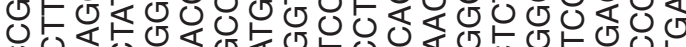
0 O

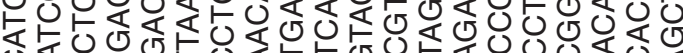

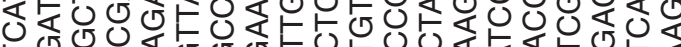

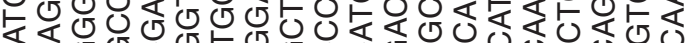

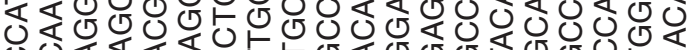
U O

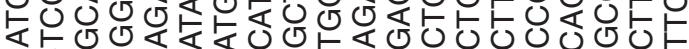

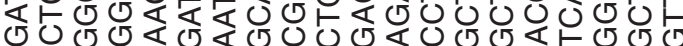

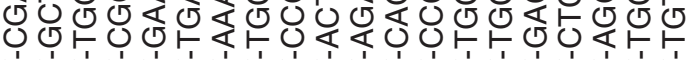

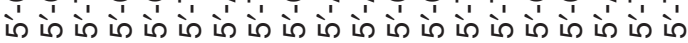

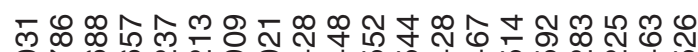

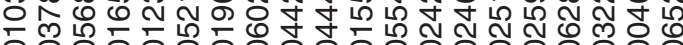
훙ㅇㅇㅇㅇㅇㅇㅇㅇㅇㅇㅇㅇㅇㅇㅇㅇㅇㅇㅇㅇㅇㅇㅇㅇㅇㅇㅇㅇㅇㅇㅇㅇㅇㅇㅇㅇ

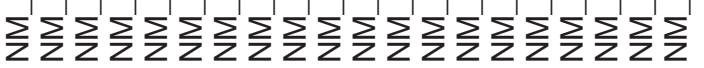




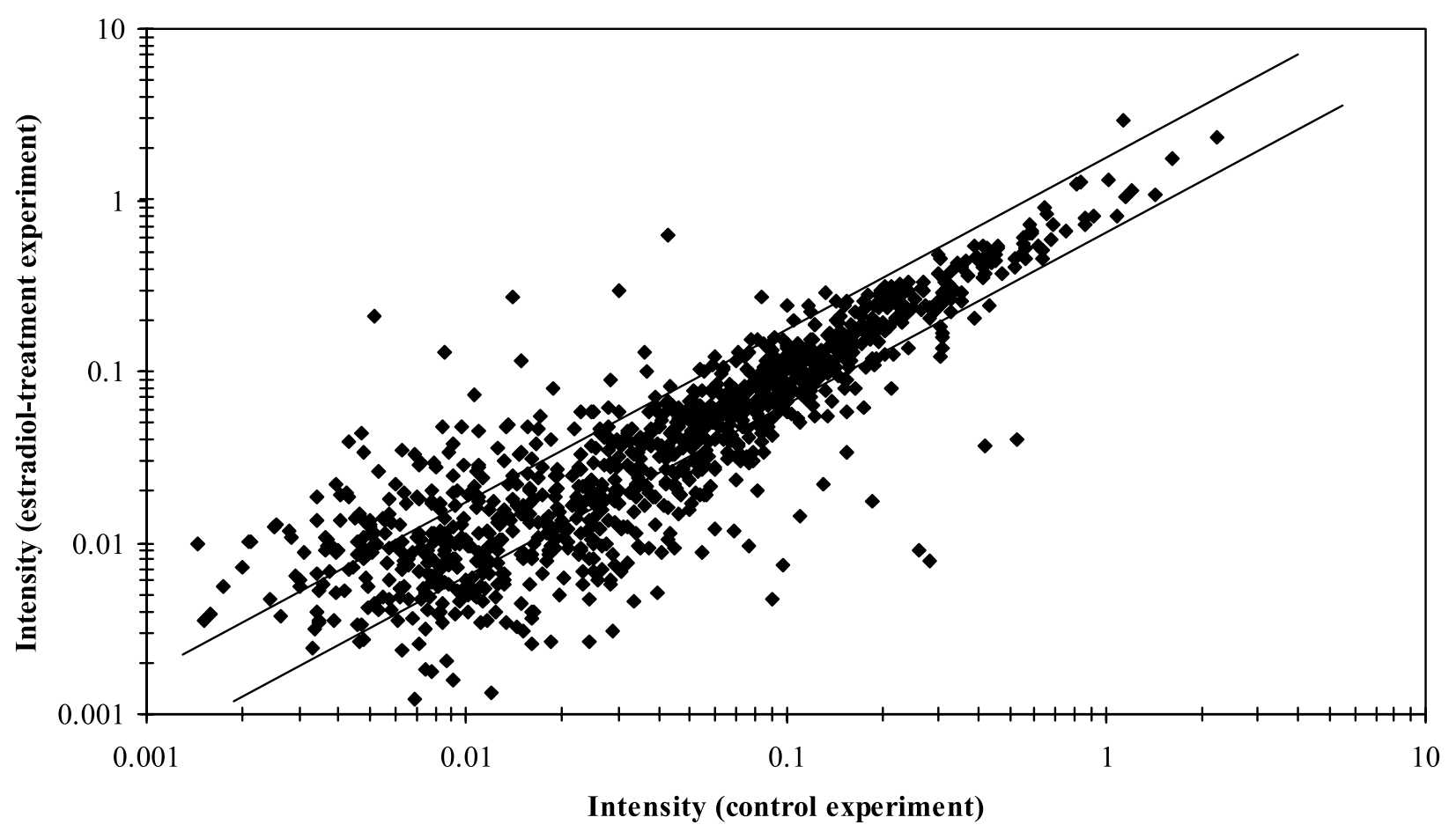

Figure 1 Correlation between the hybridization patterns of two complex probes obtained from MVLN cells treated or not treated with $\mathrm{E}_{2}$ and hybridized to two independent cDNA arrays. Solid lines indicate a 1.7-fold difference between measurements.

criteria (Bertucci et al. 1999), and the genes were chosen because of proven or putative implication in cancer. The list is available at: http://tagc. univ-mrs.fr/pub/Cancer/

\section{Hybridization of complex probe and array data analysis}

Hybridization to each array with a ${ }^{33} \mathrm{P}$-labeled probe synthesized by reverse transcribing $5 \mu \mathrm{g}$ total RNA was performed as previously described (Bertucci et al. 1999). Hybridization signals were scanned with a FUJI BAS 5000 beta imager (Raytest, Asnieres, France), then quantified with the HDG Analyzer software (Genomic Solution, Ann Arbor, MI, USA) by integrating all spot pixel intensities and removing a spot background value determined in the neighboring area. Intensity values were adjusted by a normalization step based on the DNA quantification of each spot and the sum of intensities detected in each experiment. Expression values were transformed as the ratio of the treated cell line gene value to that obtained with the corresponding untreated cell line (ratio called fold change or FG). ANOVA of logtransformed intensity values was used to assess the significance of the difference between treatments for each gene.

\section{Real-time quantitative PCR (RTQ-PCR) analysis}

RTQ-PGR was performed using a LightCycler (Roche, Meylan, France) in combination with the LightCycler Faststart DNA Master Sybr Green I (Roche). A specific set of primers was chosen for each gene of interest (Table 1). cDNA reverse transcription was performed on $1 \mu \mathrm{g}$ DNase-treated total RNA with M-MLV Reverse Transcriptase (Invitrogen, Carlsbad, CA, USA) and $0.5 \mu \mathrm{g}$ hexamer (Amersham Biosciences, Orsay, France) according to the manufacturer's instructions. For each set of primers, a standard curve was made with serial dilutions from a control cDNA sample in order to evaluate the efficiency of the primers and to relatively quantify the expression level of each sample. All measurements were normalized to 
the expression of the ribosomal $28 S$ gene, considered as a stable housekeeping gene.

\section{Western blot}

Cells were lysed in the presence of $1 \%$ Triton $\mathrm{X}-100,1 \%$ sodium deoxycholate, $0 \cdot 1 \%$ SDS, $1 \mathrm{mM}$ dithiothreitol, $2 \mathrm{mM}$ sodium fluoride and protease inhibitor in $20 \mathrm{mM}$ Tris, $150 \mathrm{mM} \mathrm{NaCl}$ (pH 7.5). For each sample, $50 \mu \mathrm{g}$ total protein were separated on SDS-PAGE gels before transferring to polyvinylidene difluoride membrane (SigmaAldrich). Membranes were then incubated with the appropriate primary antibody, and detection was performed as recommended by the manufacturers with horseradish peroxidase-conjugated secondary antibody using the ECL plus Western blotting detection system (Amersham Biosciences). ABCC5 antibody was from Monosan (Uden, The Netherlands), cyclin A2 antibody from Sigma Chemical Go (St Louis, MO, USA), insulin receptor 1 substrate (IRS1) antibody from Santa Cruz Biotechnology, Inc. (Santa Cruz, CA, USA), transforming, acidic, coiled-coil-containing protein1 (TACG1) antibody from Upstate Biotechnology Inc. (Lake Placid, NY, USA), proliferating cell nuclear antigen (PCNA) antibody from eBioscience (San Diego, CA, USA), amphiregulin antibody from Lab Vision Corporation (Fremont, CA, USA) and insulin-like growth factor-binding protein-4 (IGFBP4) antibody from USBiological (Swampscott, MA, USA). TFF1 (pS2) antibody was kindly provided by Dr M C Rio (Strasbourg, France).

\section{Results}

\section{Identification by cDNA arrays of known and novel genes in MVLN cells following $E_{2}$ treatment}

We assessed variations in gene expression induced after 4 days of exposure to $\mathrm{E}_{2}$ of the MVLN cell line using home-made cDNA mini-arrays, as described in Materials and methods. Analysis of the hybridization signatures demonstrated that the $\mathrm{E}_{2}$ treatment of the MVLN cells induced marked changes in expression of a set of genes (Fig. 1). As it is important to reproduce cDNA array experiments to verify the reliability of the data, we performed our study on three independent cell culture replicates. Since a slight variation in gene expression might have important phenotypic consequences, we considered as regulated those genes whose expression variation (called fold change or $\mathrm{FG}$ ) was greater than $1 \cdot 7$. The choice of the FG cut-off value was based on reproducibility studies of our gene expression data performed in repeated measurements, independent preparations of complex probes and independent pharmacological treatments of MVLN cell cultures (data not shown). We also considered that, by exploring independent cell culture replicates, we would be working under stringent conditions for data analysis (biological variability), thus even allowing consideration as significant gene expression variations with a low FC. Analysis of the data gave rise to 208 genes whose expression modulation was reproduced in at least two cell replicates. We then focused on 22 genes whose expression variation under $\mathrm{E}_{2}$ treatment was observed in all three cell replicates (12 up-regulations and 10 down-regulations) (Fig. 2 and Table 2). AREG, TFF1, MYC, FOS, PGR, PCNA, CTSD, IGFBP4 and $E R B B 2$ have already been reported as $\mathrm{E}_{2}-$ responsive genes in $\mathrm{ER}+$ human breast cancer cells (Jakowlew et al. 1984, Cavailles et al. 1988, van der Burg et al. 1989, Russell \& Hung 1992, Martinez-Lacaci et al. 1995, Jorgensen et al. 1998, Qin et al. 1999) and thus validated our study. We confirmed recent data by identifying the upregulation of IRS1, WNT2 and CCNA2 under $\mathrm{E}_{2}$ exposure (Katoh 2001, Mauro et al. 2001, Hodges et al. 2003). Interestingly, we identified new variations of expression under $\mathrm{E}_{2}$ treatment of the following genes: CSTA, MMP15, DLEU2, NOV, ZNF217, TACC1, EFNA1, UGT1A1, ABCC3 and $A B C C 5$. To assess the statistical significance of each of these FG values, an ANOVA was performed on log-transformed data for each gene. Except for MYC $(P=0.062), P C N A(P=0.065)$ and MMP15 $(P=0 \cdot 133)$, the $P$ value associated with ANOVA was below 0.05 for all genes, demonstrating a good correlation between the two analyses on this set of data. Although statistical tests like ANOVA and $t$-test are known to yield results different than those based on FG (Arfin et al. 2000), the good consistency we observed between both approaches is explainable by the fact that we did not select genes based only on the magnitude of their FG but also on their reproducibility in three independent experiments. 


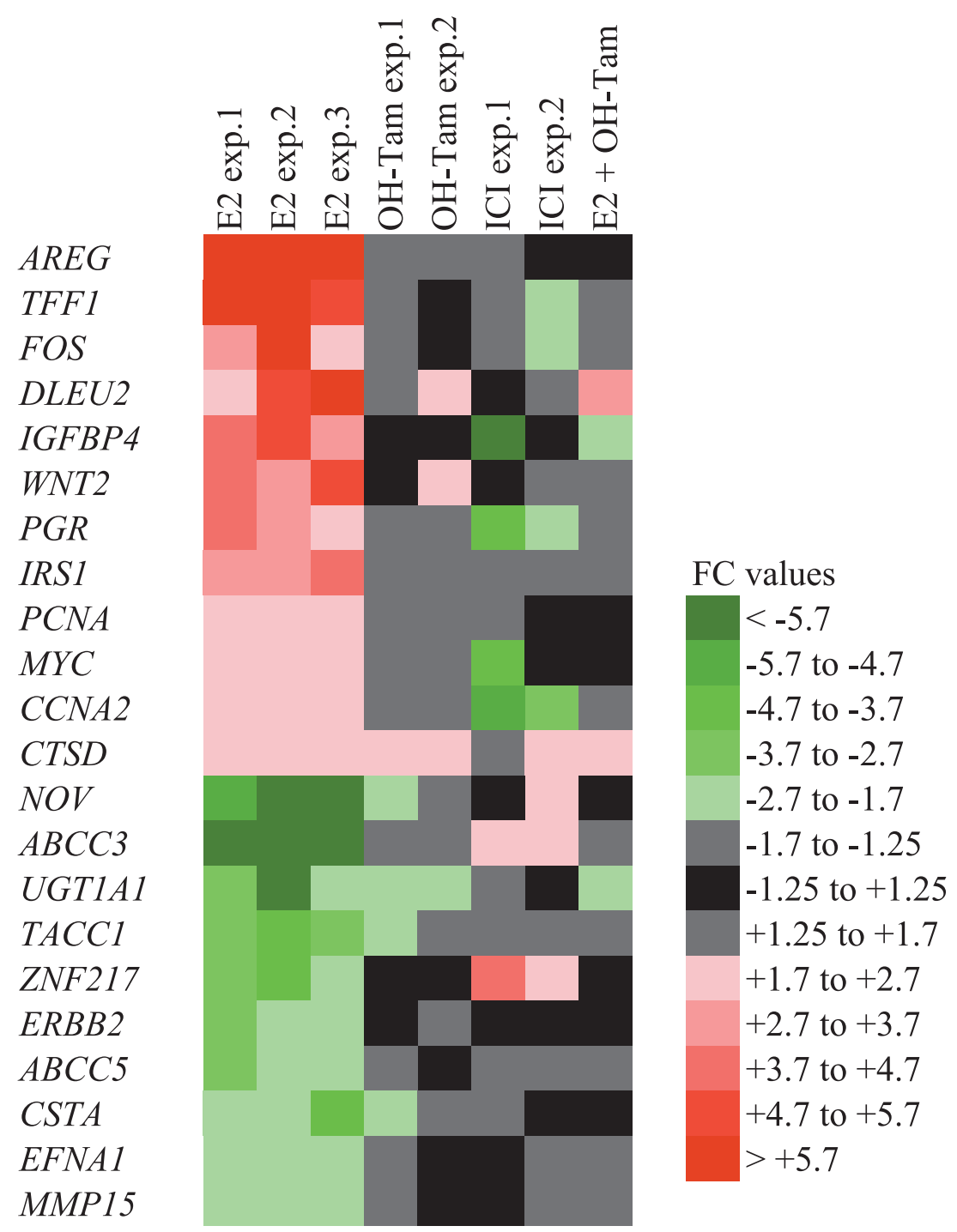

Figure 2 Gene expression variations measured by cDNA arrays in independent $\mathrm{E}_{2}$ (E2), OH-Tam, ICl 182,780 (ICl) and $\mathrm{E}_{2}+\mathrm{OH}$-Tam experiments (exp). Each row represents a gene and each column represents a different pharmacological treatment. The results are expressed in terms of FC values with a color scale indicated at the right. The data are presented for genes whose variation of expression was reproduced in three independent $\mathrm{E}_{2}$ pharmacological treatment experiments. Expression variations observed in two independent $\mathrm{OH}$-Tam experiments, two independent $\mathrm{ICl} 182,780$ experiments and one $\mathrm{E}_{2}+\mathrm{OH}$-Tam experiment are also represented. Genes highlighted in red correspond to up-regulated genes in cells under the specified pharmacological treatment compared with untreated cells $(F C>+1 \cdot 7)$. Genes highlighted in green were down-regulated $(\mathrm{FC}<-1.7)$ and genes highlighted in gray and in black were considered invariant. 


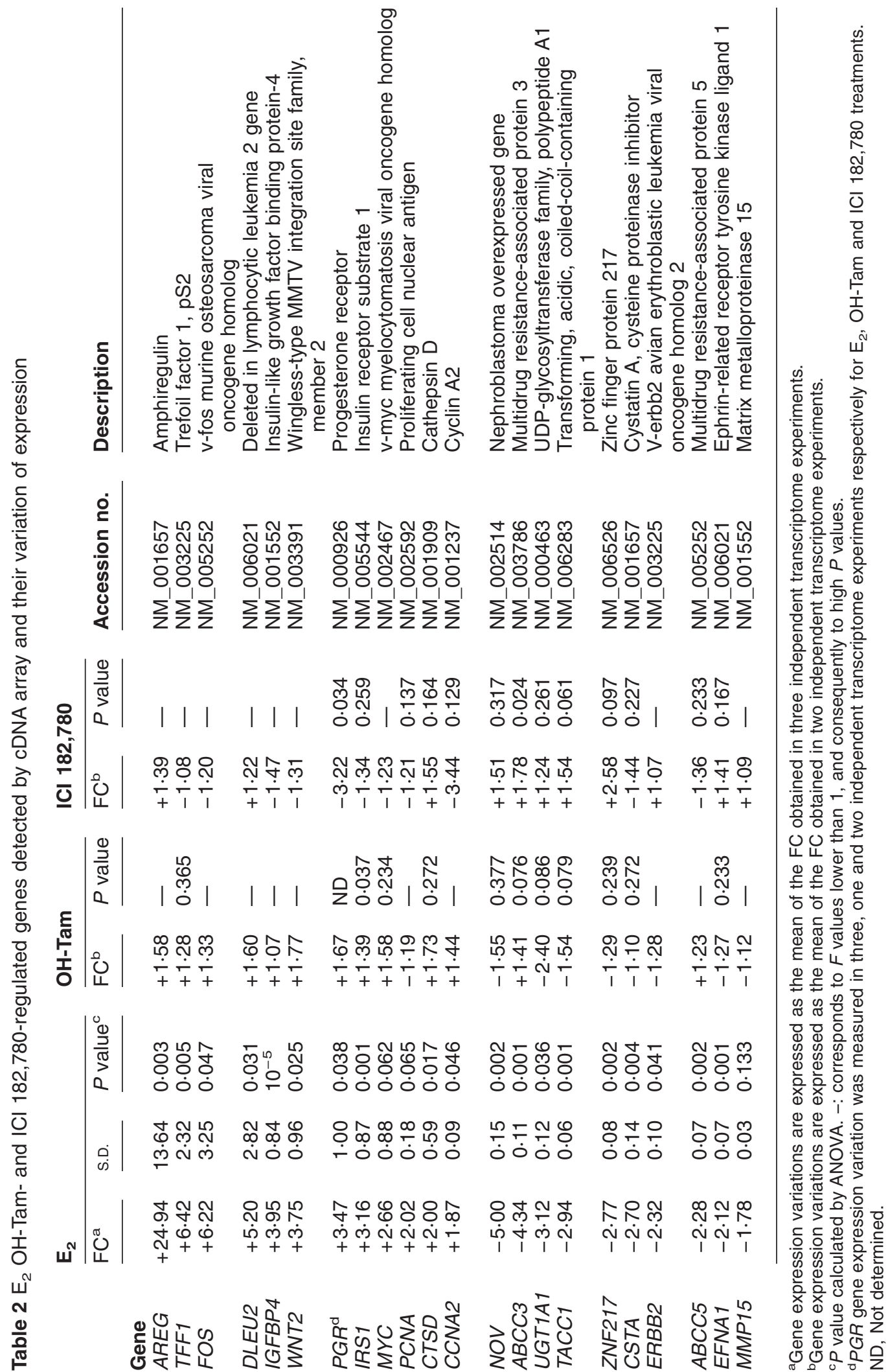


Investigation by cDNA arrays of the expression of the $E_{2}$-responsive genes in the presence of estrogen antagonists

Using our cDNA arrays, we analyzed the effects of anti-estrogens, that is, the SERM OH-Tam and the pure antagonist ICI 182,780, on the expression of the 22 estrogen-responsive genes (Fig. 2 and Table 2), to assess the specificity of the $\mathrm{E}_{2}$ response. None of the variations detected under the pharmacological action of $\mathrm{E}_{2}$ were observed under ICI 182,780 treatment. On the contrary, ICI 182,780 seemed to exhibit a 'reversed' pharmacology, that is, ICI 182,780 treatment induced reproducible down-regulation of expression of the $P G R$ and CCNA2 genes (which were up-regulated under $\mathrm{E}_{2}$ treatment) and the reproducible upregulation of two $\mathrm{E}_{2}$ down-regulated gene expressions (ABCC3 and ZNF217). The OH-Tam signature was different from that of $\mathrm{E}_{2}$ as the majority of the genes did not display any variation of expression, and from that of ICI 182,780 as no 'reversed' pharmacology was observed. Interestingly, we detected a partial agonistic action of OH-Tam, highlighted by an identical regulation of expression of a few genes under $\mathrm{E}_{2}$ or $\mathrm{OH}$-Tam treatment (e.g. the UGT1A1 gene which presented a reproducible decrease in expression after exposure to $\mathrm{E}_{2}$ or to OH-Tam). Finally, the specificity of the $\mathrm{E}_{2}$ response was reinforced by the fact that when cells were grown in the presence of both $\mathrm{E}_{2}$ and $\mathrm{OH}-\mathrm{Tam}$, this treatment was able to abolish the $\mathrm{E}_{2}$-induced modulations of expression of all the genes (Fig. 2), except for UGT1A1, CTSD and DLEU2 on which OH-Tam seemed to exert an agonistic action.

\section{Validation of array data by RTQ-PCR}

We further investigated the reliability of the data obtained by cDNA arrays by RTQ-PGR on 19 genes. A differentially expressed gene detected by cDNA array analysis ( $\mathrm{FC}>1 \cdot 7)$ was considered to be validated by RTQ-PGR if the relative expression ratio determined by this technique was equal to or greater than twofold. The resulting data are presented in Fig. 3, and demonstrate a good correlation between the two techniques (even for genes with a low FC like MMP15, PCNA, ERBB2, CTSD, CCNA2 and EFNA1). We validated $100 \%$ of the $\mathrm{E}_{2}$-induced modulations of expression, even for genes displaying an $\mathrm{FG}$ very close to the chosen cut-off (e.g. MMP15 $\left(\mathrm{FG}_{\text {array }}=-1 \cdot 78\right)$ and CCNA2 $\left.\left(\mathrm{FC}_{\text {array }}=+1 \cdot 87\right)\right)$. We also validated the downregulation of UGT1A1 by OH-Tam, the upregulations of ZNF217 and $A B C C 3$ by ICI 182,780 and the down-regulation of CCNA2 by ICI 182,780. Interestingly, the IRS1 gene, whose expression profile following $\mathrm{OH}-\mathrm{Tam}$ treatment did not display an $\mathrm{FG}$ value above $1.7\left(\mathrm{FG}_{\text {array }}\right.$ $=+1 \cdot 39)$, but which had a significant $P$ value $(P=0.037)$, was found to be up-regulated by RTQ-PGR $(\mathrm{FC}=+2 \cdot 48)$. Taken together, we validated $87 \cdot 7 \%$ of the relative gene expression modulations detected by the cDNA array experiments (50/57 measurements), demonstrating the high quality of our data. These results suggest first that, in agreement with other groups (Rajeevan et al. 2001, Galon et al. 2002), there was an excellent consistency between the cDNA results and the RTQ-PGR measurements, and secondly that transcriptome data analysis of independent cell replicates according to the $\mathrm{FC}$ value (as low as $1 \cdot 7$ ) gave reliable data, substantiated by ANOVA.

\section{Time-course study of gene modulation}

To explore the temporal response of gene expression regulation, measurements were performed at two different times. Briefly, MVLN cells grown in steroid-depleted medium for 5 days were then supplemented with $10^{-9} \mathrm{M} \mathrm{E}_{2}$ for 6,18 and $96 \mathrm{~h}$ before harvesting. Gene expression variations quantified by RTQ-PCR are illustrated in Fig. 4 and revealed different groups. Nine genes $(A R E G$, IGFBP4, TFF1, UGT1A1, EFNA1, ERBB2, ZNF217, TACC1 and ABCC5) responded after $6 \mathrm{~h}$ of $\mathrm{E}_{2}$ treatment (Fig. $4 \mathrm{~A}-\mathrm{C}$ ): the response was amplified over the time period studied for $A R E G$, IGFBP4, TFF1 and UGT1A1 (Fig. 4A); the range of the response was roughly identical at the different time points tested for the EFNA1, ERBB2, ZNF217 and TACC1 genes (Fig. 4B); on the contrary, the response of only one gene, $A B C C 5$, was maximal at $6 \mathrm{~h}$ of $\mathrm{E}_{2}$ treatment (Fig. 4G). Expression variation of six genes (DLEU2, CCNA2, IRS1, ABCC3, CSTA and $\mathcal{N O V}$ ) could only be detected after $18 \mathrm{~h}$ of $\mathrm{E}_{2}$ treatment (Fig. 4D). For the DLEU2 and CCNA2 genes, the temporal response was practically identical at $96 \mathrm{~h}$, whereas for the IRS1, $A B C C 3$, CSTA and NOV genes, the magnitude of variation of expression increased between 18 and $96 \mathrm{~h}$. 
Finally, variation of expression of the PCNA and MMP15 genes was detectable only after $96 \mathrm{~h}$ of $\mathrm{E}_{2}$ treatment (Fig. 4E).

\section{Effect of $\mathrm{CHX}$ on gene modulation}

To investigate whether protein synthesis was needed for the modulation of gene expression, we analyzed the mRNA levels in MVLN cells following $\mathrm{E}_{2}$ treatment in the presence or the absence of the protein synthesis inhibitor CHX. A similar set of MVLN cells grown in the presence of CHX alone was used as control. Based on the data obtained in the presence of $\mathrm{CHX}$ co-treatment, the variation of expression of AREG, IGFBP4, TFF1, IRS1, DLEU2, UGT1A1, ERBB2, NOV and ABCC5 following $\mathrm{E}_{2}$ treatment did not require de novo protein synthesis (Table 3). On the contrary, the variation of expression observed for CCNA2, TACC1 and ABCC3 was totally abolished in the presence of CHX, suggesting that downstream pathways are involved in this regulation. It is interesting to note that the mechanisms of $\mathrm{E}_{2}$ regulation of the $A B C C 3$ and $A B C C 5$ genes under $\mathrm{E}$ treatment were apparently different, although these genes belong to the same gene family. Concerning EFNA1 and ZNF217 (data not shown), it was difficult to draw a conclusion because CHX treatment alone increased the level of these transcripts (such an effect of CHX has already been attributed to its capacity to inhibit labile nucleases and thereby to increase the half-life of short-lived transcripts (Almendral et al. 1988)).

\section{Effect of $E_{2}$ treatment on protein level modulation}

We performed Western blot analyses of MVLN cell lysates following 24 and $96 \mathrm{~h}$ of $\mathrm{E}_{2}$ treatment to investigate the relevance of the variations of expression we selected by mini-arrays. The results obtained with the TFF1 (pS2), amphiregulin, IRS1, IGFBP4, PGNA, cyclin A2, TACG1 and ABCG5 proteins are illustrated in Fig. 5 and showed that: immunoreactive TFF1 (pS2), amphiregulin, IRS1, IGFBP4 and cyclin A2 protein levels were found to be increased in MVLN cells treated with $\mathrm{E}_{2}$ for 24 or $96 \mathrm{~h}$; immunodetection of the increased PGNA protein level was visible only after $96 \mathrm{~h}$ of $\mathrm{E}_{2}$ treatment; the ABCG5 protein level was decreased following $96 \mathrm{~h}$ of exposure to estrogens (the immunoreactive signal following $24 \mathrm{~h}$ of $\mathrm{E}_{2}$ treatment was too faint to be able to draw a conclusion). These data are totally in accordance with the mRNA level variations of the corresponding genes (Fig. 4). We also observed a decrease in the TACG1 protein level after $96 \mathrm{~h}$ of $\mathrm{E}_{2}$ treatment, again validating our mRNA data (Fig. 4). Although we were not able to detect TACG1 protein level variation after $24 \mathrm{~h}$ of $\mathrm{E}_{2}$ treatment (whereas TACC1 mRNA level variation was detectable; Fig. 4), kinetic studies revealed that the decrease in TACG1 protein level following $\mathrm{E}_{2}$ treatment could, however, be detected after 48 and $72 \mathrm{~h}$ of estrogen exposure (data not shown). Taken together, our work demonstrated an excellent correlation between expression variations detected at the mRNA level and at the protein level, validating the relevance of the expression modulations we identified. Moreover, it is important to draw attention to the results obtained with the ABCG5 and cyclin A2 proteins because they demonstrate that low $\mathrm{FG}$ selected by transcriptome data analysis $\left(\mathrm{FG}_{\text {array }} C C N A 2=+1.87 ; \quad \mathrm{FG}_{\text {array }}\right.$ $A B C C 5=-2 \cdot 28)$ can be validated by both RTQPCR and Western blotting. This observation reinforces the fact that an FC cut-off value as low as 1.7 can be chosen in transcriptome experiments involving independent cell replicates to generate reliable data.

\section{Discussion}

The aim of this work was to identify novel genes whose expression was specifically regulated under $\mathrm{E}_{2}$ treatment. Such genes might encode proteins playing a critical role in hormone-responsive tissues and cancer and could be new candidates as potential diagnostic/prognostic tools for hormonedependent breast cancers. Our belief was that one of the criteria to select such candidates should be to consider genes whose estrogen regulation is persistent and, thus, could reflect the physiological exposure to endogenous estrogens. For this reason, we set up the estradiol pharmacologic treatment for 4 days.

Among the 22 selected genes were new downstream $\mathrm{E}_{2}$ gene effectors, for which the specificity of the $\mathrm{E}_{2}$ response was reinforced by the fact that it was abolished for most of them by 
(A)
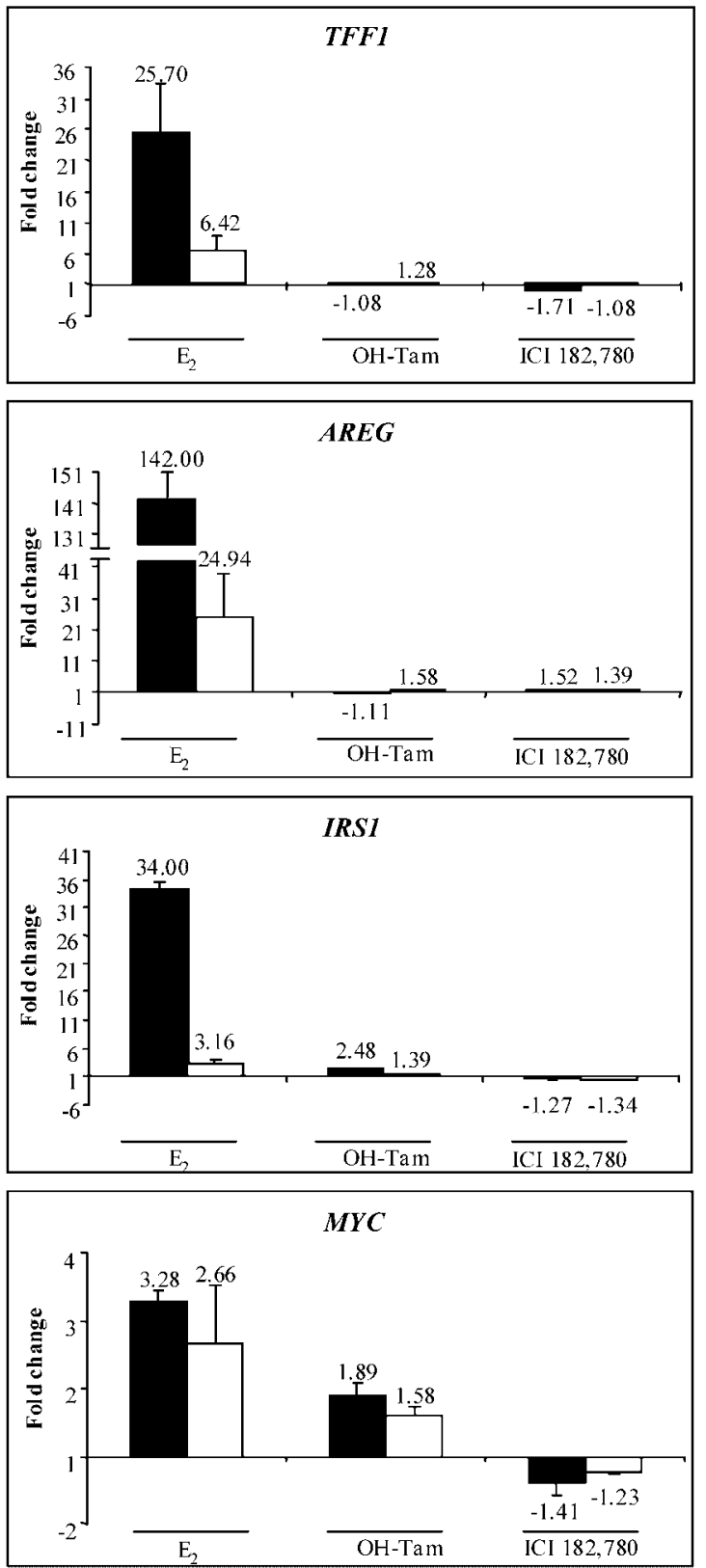

(B)

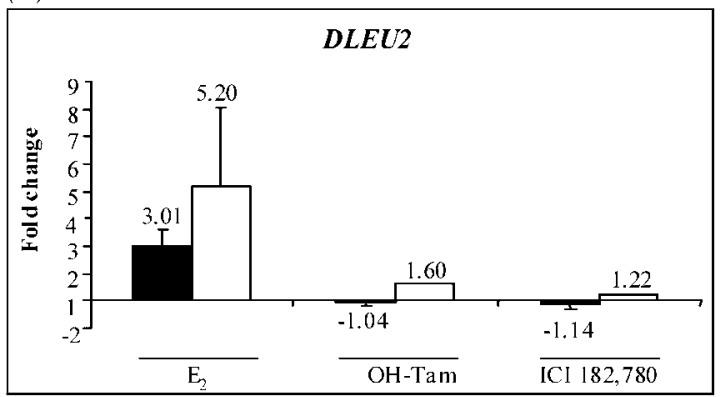

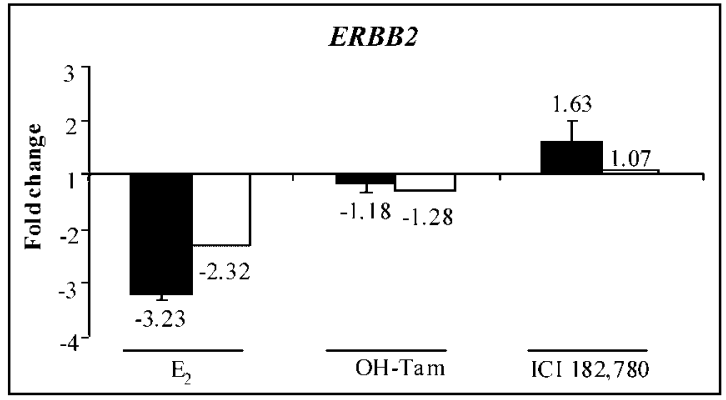
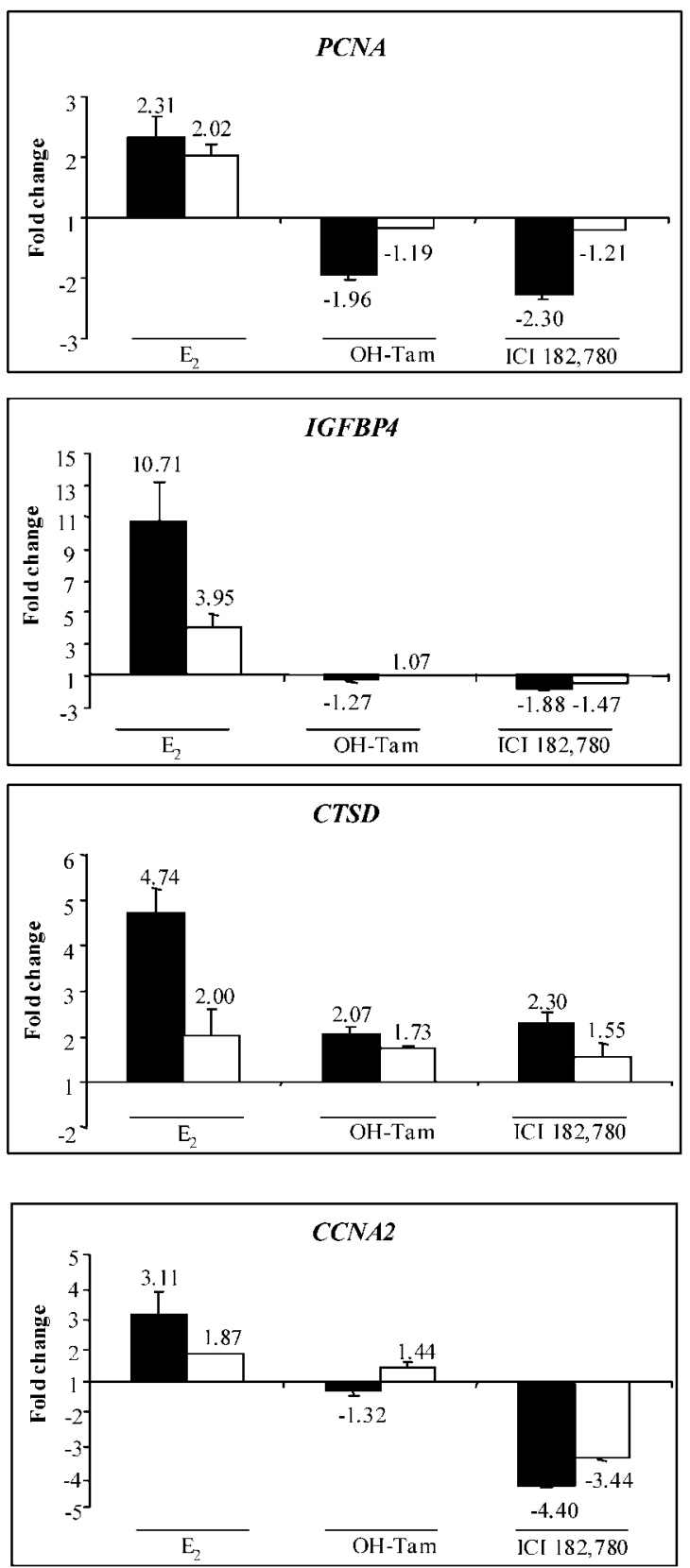
(B)
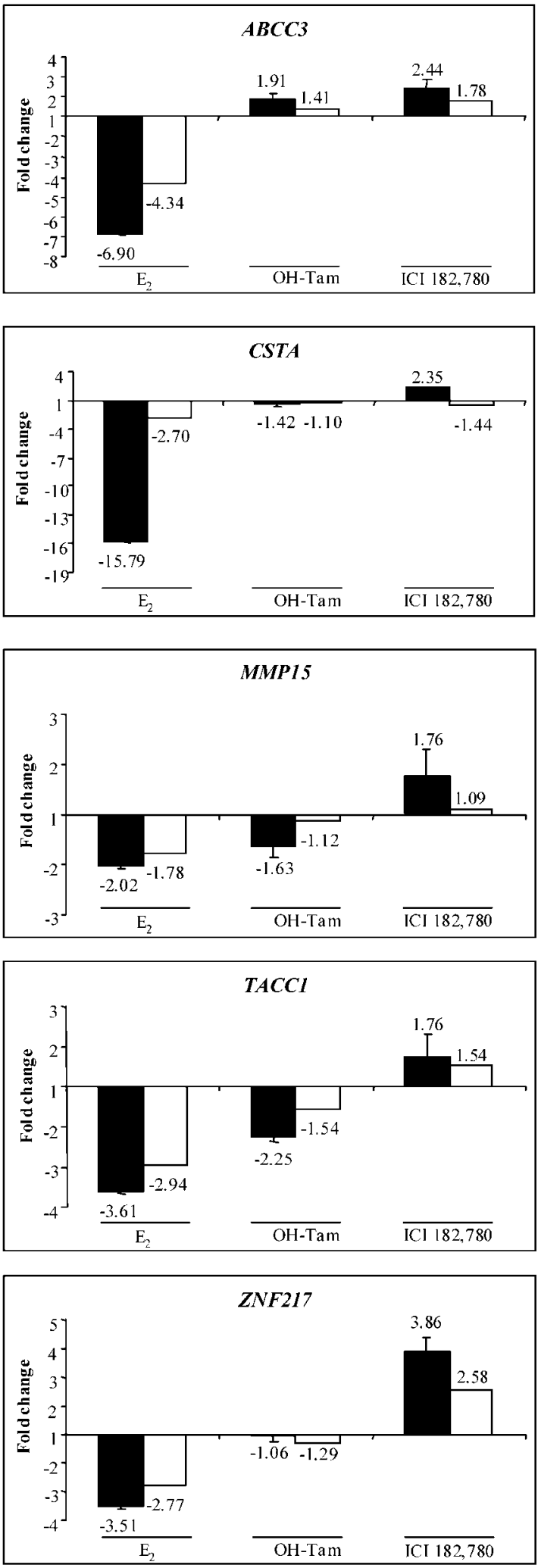

www.endocrinology.org
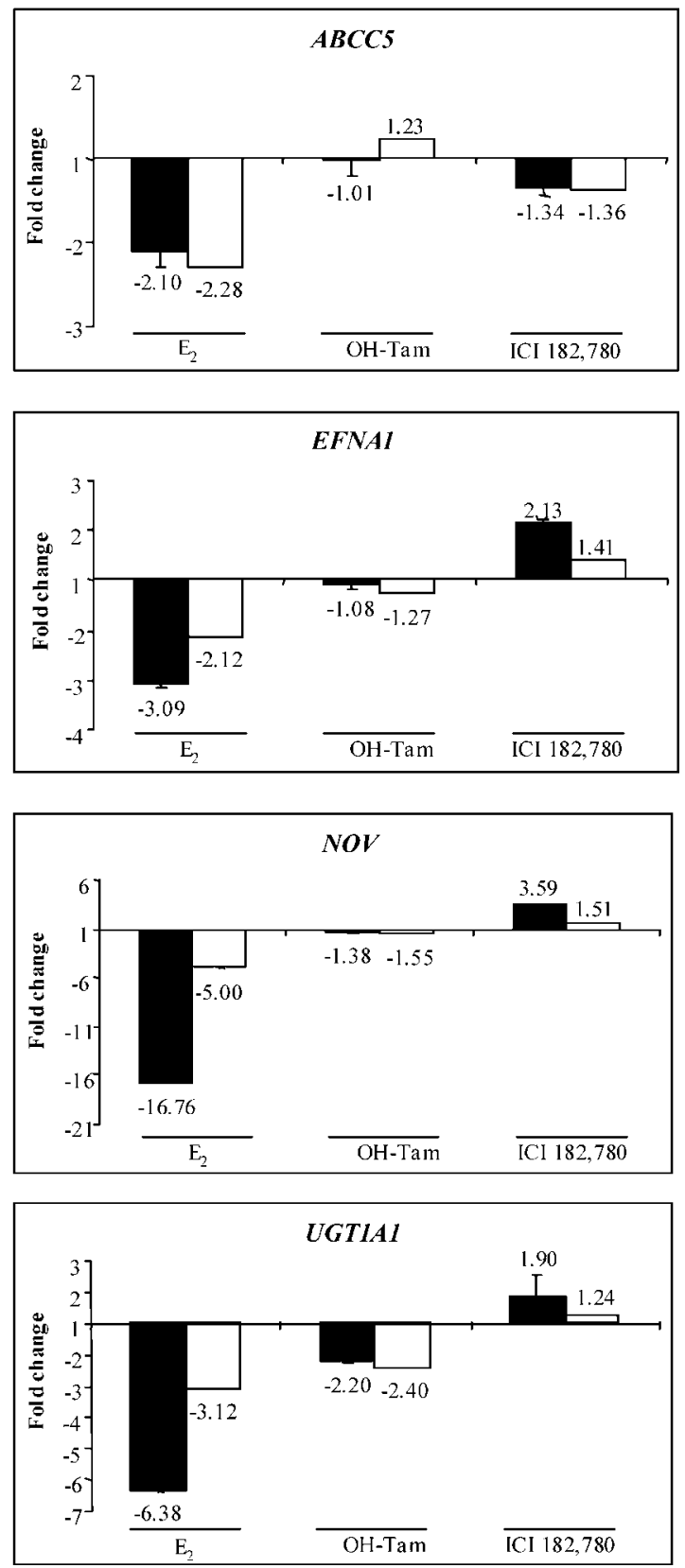

Figure 3 Comparison of the gene expression variations (fold change) measured by RTQ-PCR (solid columns) and CDNA arrays (open columns) after 4 days of $\mathrm{E}_{2}, \mathrm{OH}-\mathrm{Tam}$ or $\mathrm{ICl} 182,780$ treatment of MVLN cells. The RTQ-PCR values indicated are the mean of at least three independent experiments. (A) Genes whose $E_{2}$-induced regulation have already been documented. (B) Novel $\mathrm{E}_{2}$-induced gene expression regulations. 
(A)
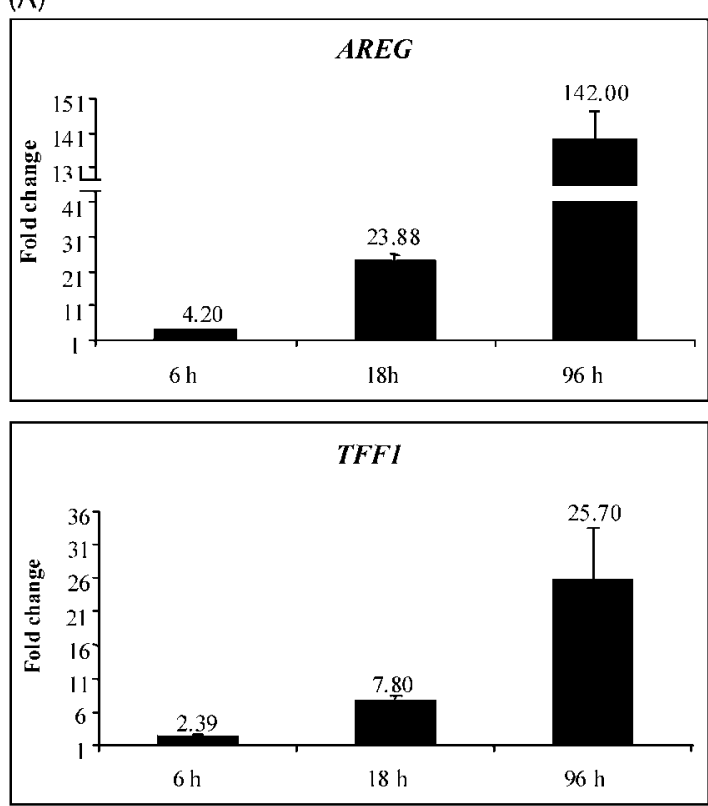

(B)
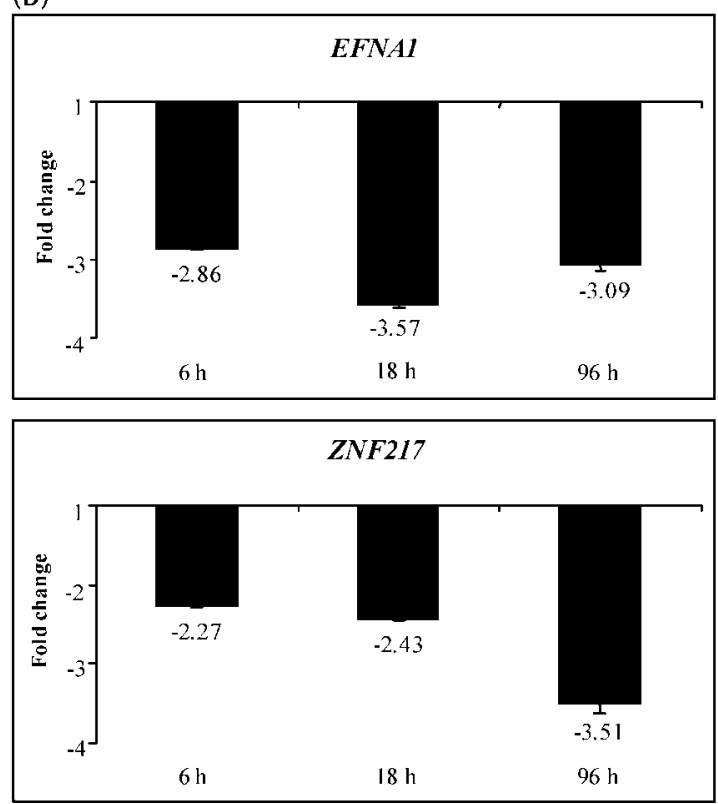

(C)

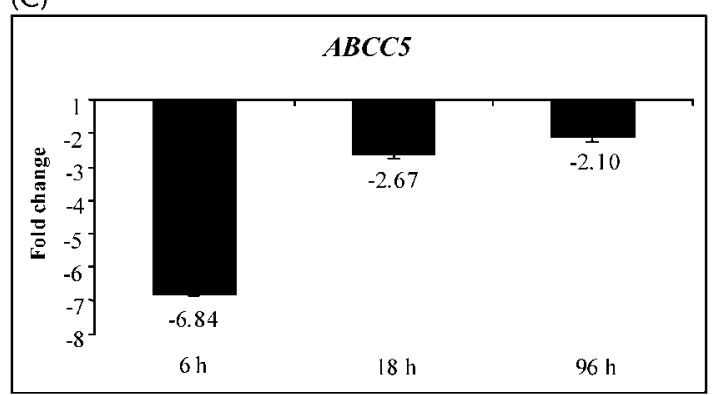

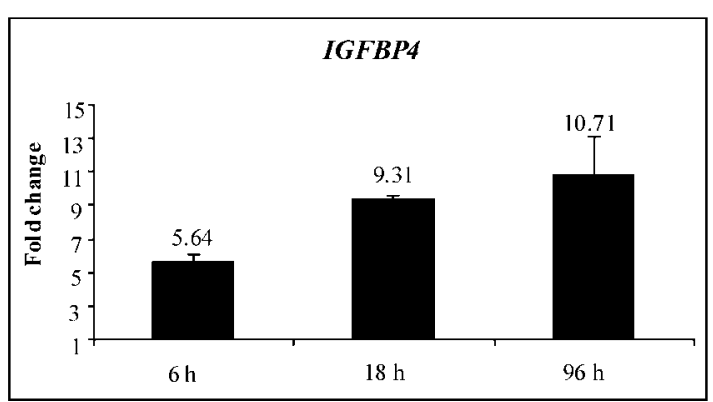
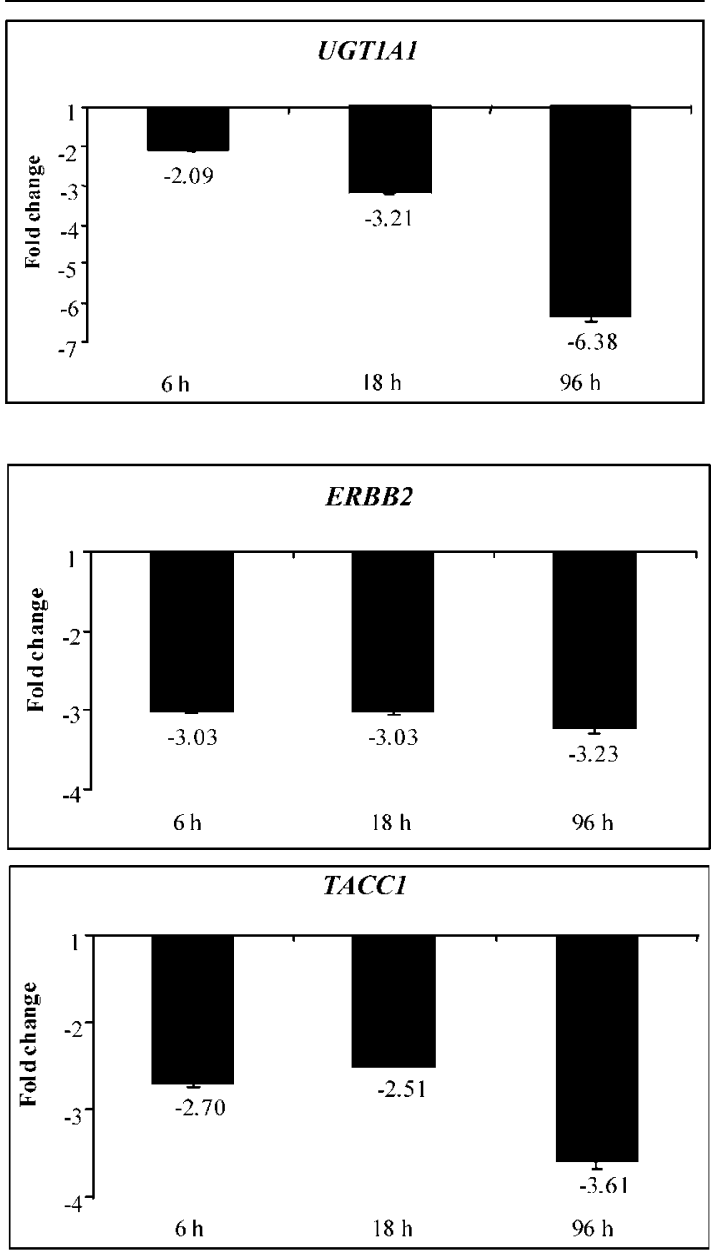
(D)
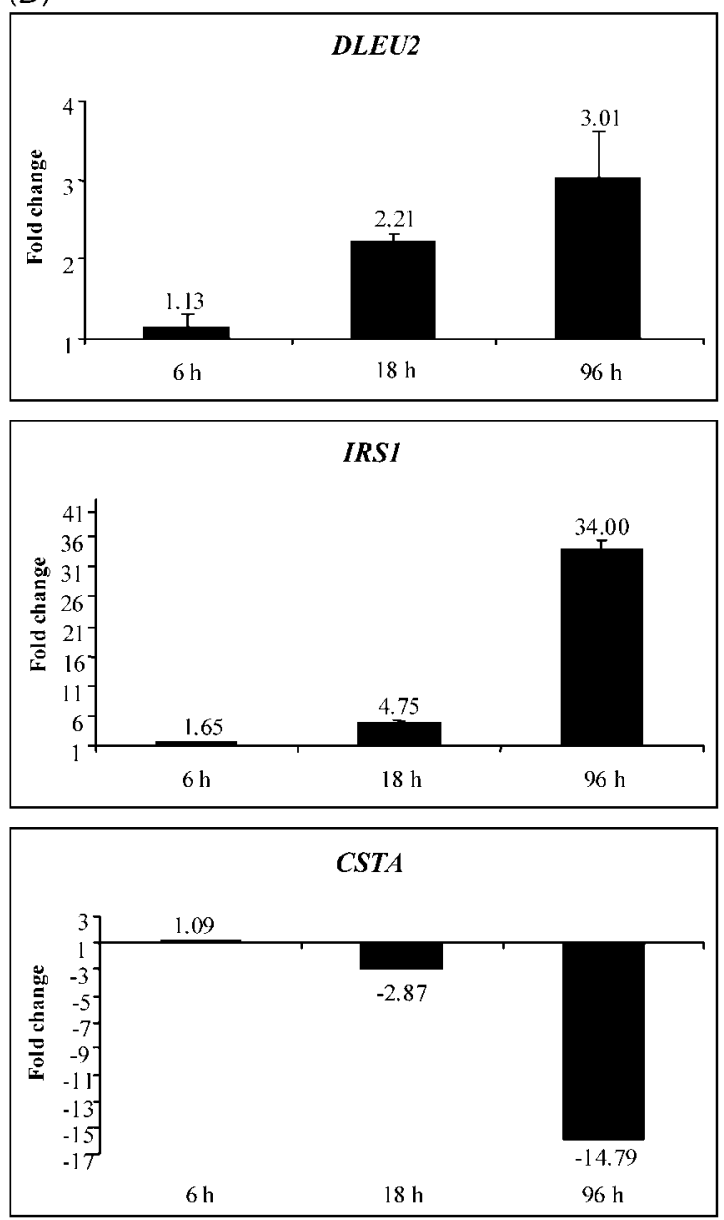

(E)

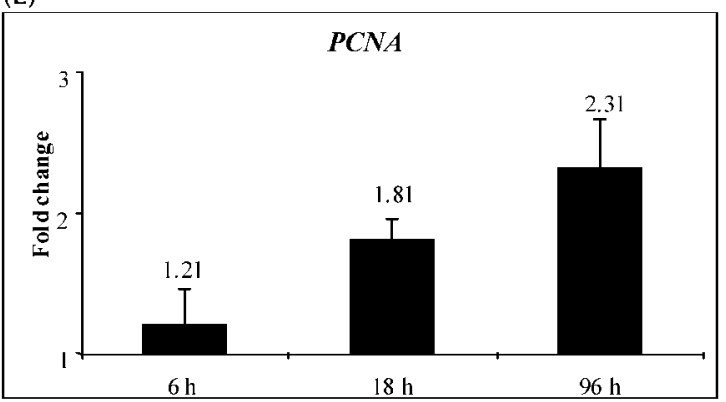

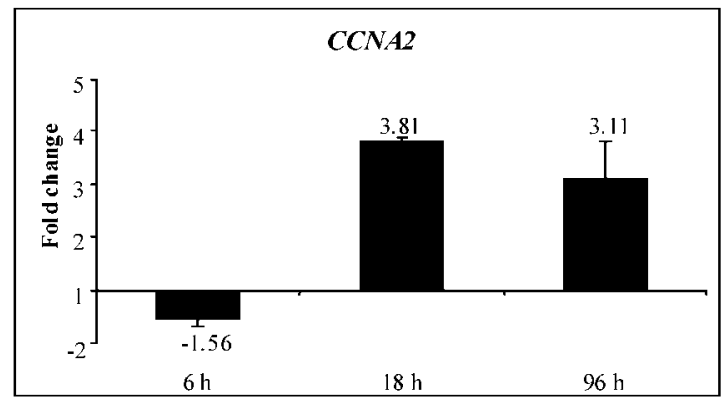
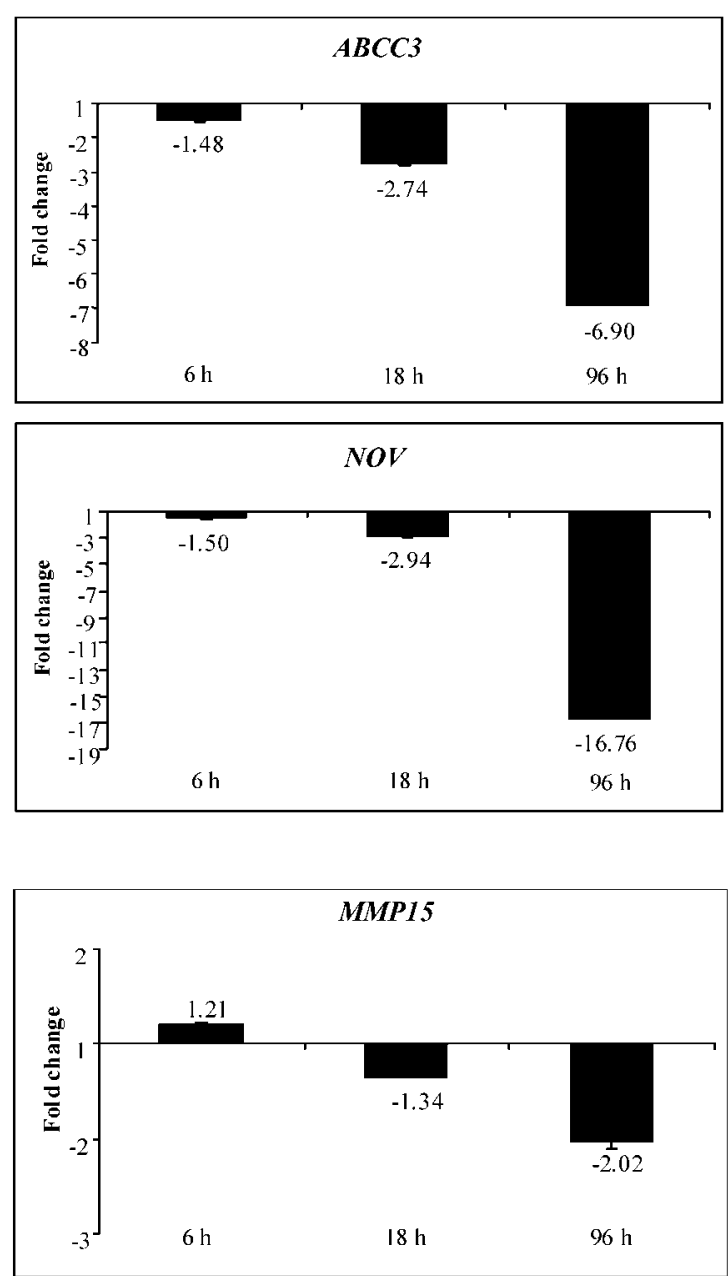

Figure 4 Time-course study of genes under $\mathrm{E}_{2}$ treatment. Gene expression variations were measured by RTQ-PCR after 6,18 and $96 \mathrm{~h}$ of $\mathrm{E}_{2}$ treatment of MVLN cells. The results are expressed in terms of mean FC values obtained in at least three independent experiments. (A-C) Genes whose expression variation was detectable after $6 \mathrm{~h}$ of $\mathrm{E}_{2}$ treatment and with: $(\mathrm{A})$ an expression which increased during the treatment; (B) an expression practically identical at the different time points studied; (C) a maximal expression at $6 \mathrm{~h}$. (D) Genes whose expression variation was detected only after $18 \mathrm{~h}$ of treatment. (E) Genes whose expression variation was detected only after $96 \mathrm{~h}$ of treatment. 
Table 3 Effect of $\mathrm{CHX}$ on $\mathrm{E}_{2}$-regulated genes ${ }^{\mathrm{a}}$

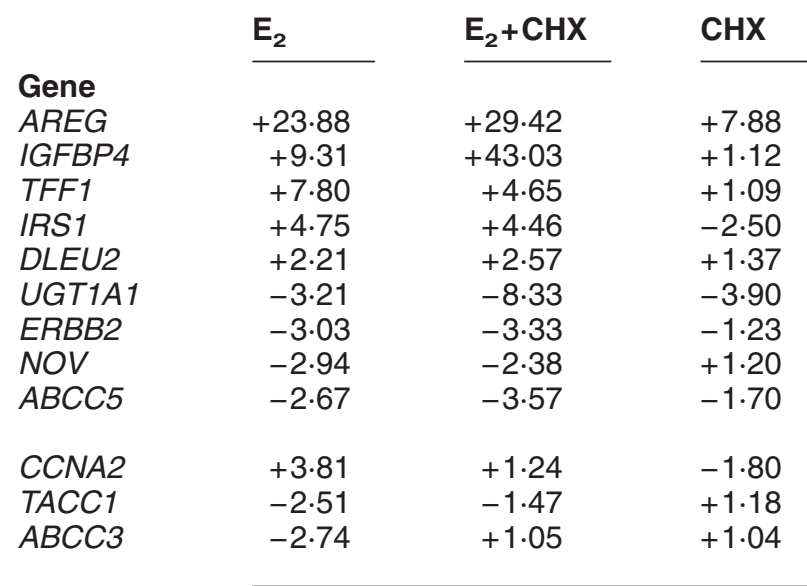

${ }^{a}$ Gene expression variations were measured by RTQ-PCR after $18 \mathrm{~h}$ of $\mathrm{E}_{2}$ treatment of MVLN cells in the presence or absence of $\mathrm{CHX}$. The results are expressed in terms of mean FC values, obtained in at least three independent experiments.

$\mathrm{OH}-\mathrm{Tam}$. This is in agreement with the antagonistic action of OH-Tam and suggests that these genes are regulated by $\mathrm{E}_{2}$ through ER-dependent mechanisms or pathways. Understanding the effects of estrogen antagonists is also of interest because they have been developed for antihormone therapy and their impact on $\mathrm{E}_{2}$ target genes is not fully understood. Treatment of the MVLN cells by ICI 182,780 globally showed a 'reversed' pharmacology (the most striking examples were the genes CCNA2 and ZNF217). This can be explained by the fact that residual estrogen activity might persist in the medium where the MVLN cells were grown. Under such conditions, the ICI 182,780 pharmacological signature might be the consequence of the inhibition of this residual estrogen activity, amplified by the decrease of the ER proteins induced by this molecule (Pink \& Jordan 1996). The OH-Tam hybridization signature was different from that observed with $\mathrm{E}_{2}$ and ICI 182,780, as most of the genes did not display any expression difference or any 'reversed' response. This can probably be explained by the complexity of the pharmacology of the SERM $\mathrm{OH}-\mathrm{Tam}$, as cell-type and promoter-specific differences in co-regulator recruitment play a critical role in determining the cellular response to OH-Tam (Shang \& Brown 2002). Thus, the subtle pharmacology of the OH-Tam molecule, added to the fact that this molecule triggers the accumulation of the ER protein in MCF-7 cells (Pink \& Jordan 1996), might explain the difference in hybridization signatures observed between this molecule and ICI 182,780. Interestingly, we also highlighted a partial agonistic action of OH-Tam as revealed by the UGT1A1 gene expression data. These results suggest that in MVLN cells, UGT1A1 possesses an unidentified estrogen-responsive regulation mechanism on which OH-Tam acts as a partial agonist.

With the purpose of deciphering the mechanism of estrogen action on gene regulation, we performed kinetic and CHX studies on the IRS1, DLEU2, NOV, ABCC3, CSTA, AREG, TFF1, IGFBP4, UGT1A1, ERBB2, ZNF217, EFNA1, PCNA, MMP15, CCNA2, TACC1 and ABCC5 genes. Kinetic studies revealed that the pattern of the temporal responses varied between the genes considered. CHX studies demonstrated that inhibition of protein synthesis has no effect on the $\mathrm{E}_{2}$-induced regulation of expression of $A R E G$, IGFBP4, ERBB2, TFF1, IRS1, DLEU2, UGT1A1, $\mathcal{N O V}$ and $A B C C 5$, suggesting a direct action of $\mathrm{E}_{2}$. However, ABCC3, CCNA2 and TACC1 regulation of expression was totally abolished in the presence of CHX, suggesting a mechanism of regulation by $\mathrm{E}_{2}$ involving downstream pathways.

Besides classical interaction with the ERE, ligand-activated ERs also regulate gene expression by interacting directly with the AP-1 protein complex (Webb et al. 1999), the Spl protein (Safe 2001) and the NF-אB protein (Harnish et al. 2000). We used Genomatix GEMS Launcher software (München, Germany) to search for ER, Spl, AP-1 and $\mathrm{NF}-\mathrm{\kappa B}$ binding sites in the $2 \mathrm{~kb}$ promoter region of $A B C C 3, A B C C 5, C C N A 2, D L E U 2, E F N A 1$, NOV, UGT1A1, TACC1 and ZNF217. Genomatix software analysis led to the identification of EREs in ABCC3, ABCC5, CCNA2, DLEU2, TACC1 and $A B C C 5$ promoters; Spl binding sites were present in the promoter region of $A B C C 3, A B C C 5, C C N A 2$, DLEU2, EFNA1, NOV, TACC1 and UGT1A1 genes; AP-1 binding sites were only identified for the ABCC3 and ZNF217 genes; finally, NF-кB binding sites were present in the promoter region of ABCC3, DLEU2, TACC1 and UGT1A1. Taken together, these data suggest putative mechanisms of regulation of the expression of these genes by ER-ligand complexes. However, future work will be necessary to decipher the exact mechanism 


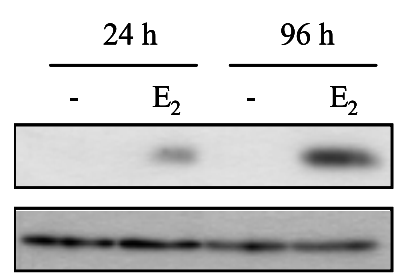

TFF1

Tubulin

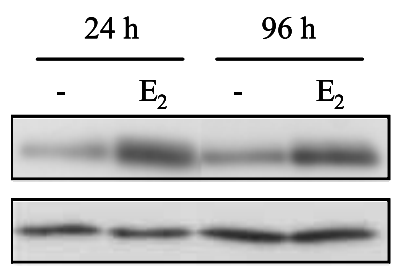

IRS1

Tubulin

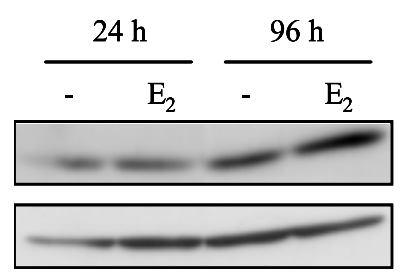

PCNA

\section{Tubulin}

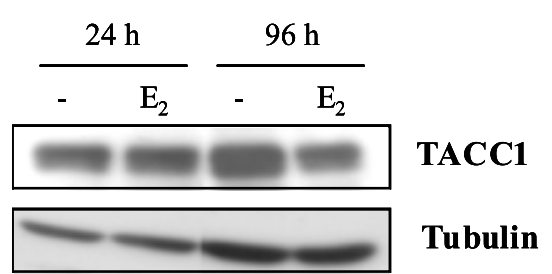

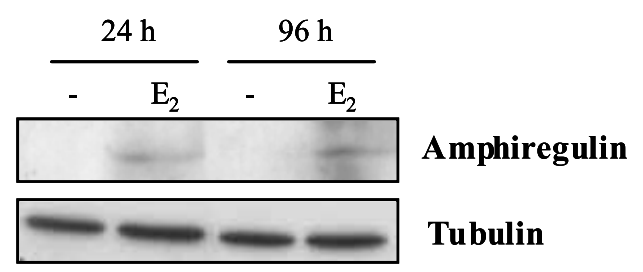
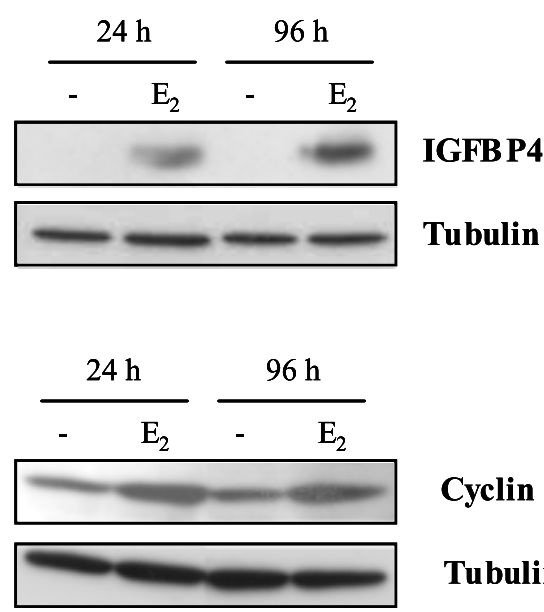

Cyclin A2

Tubulin

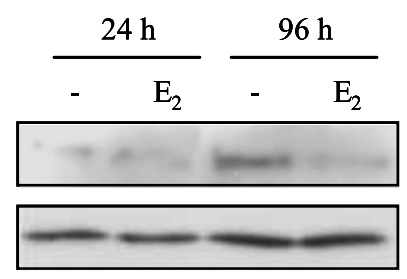

ABCC5

Tubulin

Figure 5 Western blot analysis of TFF1 (pS2), amphiregulin, IRS1, IGFBP4, PCNA, cyclin A2, TACC1 and $A B C C 5$ proteins. Protein expression was analyzed as described in Materials and methods using specific antibodies; the tubulin protein level was measured to verify even loading. Protein levels were immunodetected in MVLN cells untreated (-) or treated for 24 or $96 \mathrm{~h}$ with $1 \mathrm{nM} \mathrm{E}_{2}$.

of $\mathrm{E}_{2}$ regulation, for example, by assessing estrogen responsiveness of promoter/reporter fusion constructs.

In this study, we newly identified $\mathrm{E}_{2}$-induced down-regulation of genes potentially involved in the metabolism of estrogens (UGT1A, ABCC3 and $A B C C 5)$. Glucuronidation is a well-established metabolic route of both estradiol and tamoxifen, and the UGT1Al enzyme is a major UDPglycosyltransferase involved in estradiol glucuronidation. As the candidate proteins for glucuronide transporters have recently been described as the transmembrane transporters ABCGs (Konig et al. 1999), it is tempting to speculate that $\mathrm{E}_{2}$ down-regulates $U G T 1 A 1, A B C C 3$ and $A B C C 5$ genes to maintain a high intracellular estrogen level and thus to amplify its own pharmacological action. Interestingly, we also observed a slight downregulation of UGT1A1 under OH-Tam treatment, suggesting that this phenomenon could also occur in the $\mathrm{OH}-$ Tam metabolism.

While the potent mitogenic effect of estrogen has been known for a long time, the mechanism of estrogen-mediated proliferation is not fully understood. Of much interest is the understanding of the relevance of estrogen target genes in estrogendependent growth. In this study, we selected several genes modulating cell proliferation such as IRS1, 
IGFBP4, CCNA2 and NOV. IRS1 and IGFBP4 are involved in the cross-talk between estrogen and insulin growth factor-dependent pathway-mediated proliferation (Corcoran et al. 1996). CCNA2 encodes for a protein reported to function at the G2/M transition. The up-regulation of this gene (observed after a 4-day $\mathrm{E}_{2}$ treatment) corroborates and completes a very recent study (Hodges et al. 2003), which showed an up-regulation of CCNA2 expression in MCF-7 cells after $24 \mathrm{~h}$ of $\mathrm{E}_{2}$ treatment. We also described for the first time the $\mathrm{E}_{2}$-mediated down-regulation of $\mathcal{N O V}$ which encodes for a negative regulator of cell proliferation. The down-regulation of the $\mathcal{N O V}$ gene may be involved in malignant processes, as it has been observed in fibroblasts transformed by p60 v-SRG (Scholz et al. 1996) and is associated with the progression of adrenocortical tumors (Martinerie et al. 2001). Thus, the $\mathcal{N O V}$ down-regulation after $\mathrm{E}_{2}$ treatment suggests that this gene could be involved in estrogen-dependent pathogenic processes.

Of much interest is also the identification of new $\mathrm{E}_{2}$ target genes potentially involved in the development by estrogens of breast carcinogenesis. WNT2 expression, which has been found associated with abnormal proliferation in human breast tissue (Huguet et al. 1994), was demonstrated to be increased following $\mathrm{E}_{2}$ exposure, confirming recent data (Katoh 2001). We also described, and this for the first time, the $\mathrm{E}_{2}$-induced down-regulation of TACC1, EFNA1 and ZNF217 genes. The TACG family members are thought to contribute to the development of cancer (Raff 2002), and TACC1 mRNA down-regulations have recently been observed in breast tumors (Conte et al. 2002). Thus, the $\mathrm{E}_{2}$-induced down-regulation we identified for the TACC1 gene could be involved in the development of estrogen-dependent breast carcinogenesis. EFNA1 protein binds to a tyrosine kinase receptor (EphA2) which has a complex function. Interestingly, EphA2 stimulation by soluble ligands reverses the malignant behavior of EphA2transformed cells (Zelinski et al. 2001), and EphA2 expression is also down-regulated by estrogen (Zelinski et al. 2002). Thus, negative regulations of both EFNA1 and EphA2 could be a mechanism by which estrogen may promote mammary epithelium cell growth. The candidate oncogene $2 \mathcal{N F} 217$ has been predicted to encode alternatively spliced Krüppel-like transcription factors, which promote immortalization of human mammary epithelial cells, suggesting that aberrant expression of this gene may be selected for during breast cancer progression by overcoming senescence (Nonet et al. 2001). In this study, we identified for the first time the down-regulation of ZNF217 by estrogen in MVLN cells, and we also observed this negative regulation in the MCF-7 parental cell line (data not shown). Taken together, these data suggest $\mathrm{ER} \alpha$-dependent pathway involvement in EFNA1, TACC1 and ZNF217 expression regulation, and a potential involvement of these genes in estrogenmediated breast tumor development.

In conclusion, this study first identified and validated new estrogen downstream targets (ABCC3, ABCC5, CCNA2, DLEU2, EFNA1, MMP15, NOV, UGT1A1, TACC1 and ZNF217), and secondly pointed out for most of these genes new estrogen-mediated down-regulations. The reliability of the data presented in this work was reinforced by validation at the mRNA level or at the protein level of the gene expression variations selected by transcriptome data analysis (even for genes displaying a low FG). Given the biological function (known or putative) of the selected genes, this work provides potential candidates first for understanding the pharmacological effects of estrogens and their consequences in estrogendependent diseases, and secondly for identifying new molecular markers with potential clinical applications. The MVLN cells are a very interesting model because tamoxifen-resistant, but still estrogen-dependent, cellular clones have been isolated (Badia et al. 2000). We are now studying gene expression profiling on these resistant cellular clones to delineate the molecular mechanisms associated with the development of tamoxifen resistance. These data should enhance the understanding of changes induced by ER ligands on the transcriptional program of human $\mathrm{E}_{2}$-responsive cells and permit the identification of new potential diagnostic/prognostic tools for the monitoring of estrogen-related disease conditions such as breast cancer.

\section{Acknowledgements}

We thank Dr J C Nicolas, Dr P Martineau, Dr C Granier, Dr F Vignon and Dr S L Salhi for critical review of the manuscript. We are grateful to Dr P Chuchana for help with the bio-informatics 
analyses. This work was supported by grants from the Ligue Nationale Contre le Cancer and the Groupement des Entreprises Françaises dans la Lutte Contre le Cancer. J A V was supported by a scholarship from the Ligue Nationale Contre le Cancer (France).

\section{Note added by the author}

While this manuscript was under revision, Frasor and colleagues published new transcriptome data from MCF-7 cells and also identified downregulation of the $Z \mathcal{N} F 217$ gene upon exposure to estrogen (Frasor et al. 2003).

\section{References}

Almendral JM, Sommer D, Macdonald-Bravo H, Burckhardt J, Perera J \& Bravo R 1988 Complexity of the early genetic response to growth factors in mouse fibroblasts. Molecular and Cellular Biology 8 2140-2148.

Arfin SM, Long AD, Ito ET, Tolleri L, Riehle MM, Paegle ES \& Hatfield GW 2000 Global gene expression profiling in Escherichia coli K12. The effects of integration host factor. Fournal of Biological Chemistry 275 29672-29684.

Badia E, Duchesne MJ, Semlali A, Fuentes M, Giamarchi C, Richard-Foy H, Nicolas JC \& Pons M 2000 Long-term hydroxytamoxifen treatment of an MCF-7-derived breast cancer cell line irreversibly inhibits the expression of estrogenic genes through chromatin remodeling. Cancer Research 60 4130-4138.

Bertucci F, Van Hulst S, Bernard K, Loriod B, Granjeaud S, Tagett R, Starkey M, Nguyen C, Jordan B \& Birnbaum D 1999 Expression scanning of an array of growth control genes in human tumor cell lines. Oncogene 18 3905-3912.

van der Burg B, van Selm-Miltenburg AJ, de Laat SW \& van Zoelen EJ 1989 Direct effects of estrogen on c-fos and c-myc protooncogene expression and cellular proliferation in human breast cancer cells. Molecular and Cellular Endocrinology 64 223-228.

Cavailles V, Augereau P, Garcia M \& Rochefort H 1988 Estrogens and growth factors induce the mRNA of the 52K-pro-cathepsin-D secreted by breast cancer cells. Nucleic Acids Research $\mathbf{1 6}$ 1903-1919.

Cavailles V, Garcia M \& Rochefort H 1989 Regulation of cathepsin-D and pS2 gene expression by growth factors in MCF7 human breast cancer cells. Molecular Endocrinology 3 552-558.

Cohen P, Bouaboula M, Bellis M, Baron V, Jbilo O, Poinot-Chazel C, Galiegue S, Hadibi EH \& Casellas P 2000 Monitoring cellular responses to Listeria monocytogenes with oligonucleotide arrays. Journal of Biological Chemistry 275 11181-11190.

Conte N, Charafe-Jauffret E, Delaval B, Adelaide J, Ginestier C, Geneix J, Isnardon D, Jacquemier J \& Birnbaum D 2002 Carcinogenesis and translational controls: TACG1 is down-regulated in human cancers and associates with mRNA regulators. Oncogene 21 5619-5630.

Corcoran D, Perachiotti A \& Darbre PD 1996 Increased autocrine production of insulin-like growth factor II (IGF-II) alters serum sensitivity of MCF-7 human breast cancer cell proliferation. Cell Proliferation 29 479-493.

Demirpence E, Duchesne MJ, Badia E, Gagne D \& Pons M 1993 MVLN cells: a bioluminescent MCF-7-derived cell line to study the modulation of estrogenic activity. Fournal of Steroid Biochemistry and Molecular Biology 46 355-364.

Frasor J, Danes JM, Komm B, Chang KC, Lyttle CR \& Katzenellenbogen BS 2003 Profiling of estrogen up- and down-regulated gene expression in human breast cancer cells: insights into gene networks and pathways underlying estrogenic control of proliferation and cell phenotype. Endocrinology 144 $4562-4574$

Galon J, Franchimont D, Hiroi N, Frey G, Boettner A, Ehrhart-Bornstein M, O'Shea JJ, Chrousos GP \& Bornstein SR 2002 Gene profiling reveals unknown enhancing and suppressive actions of glucocorticoids on immune cells. FASEB foumal $\mathbf{1 6}$ $61-71$.

Harnish DC, Scicchitano MS, Adelman SJ, Lyttle CR \& Karathanasis SK 2000 The role of CBP in estrogen receptor cross-talk with nuclear factor-kappaB in HepG2 cells. Endocrinology $1413403-3411$.

Henry JA, Nicholson S, Farndon JR, Westley BR \& May FE 1988 Measurement of oestrogen receptor mRNA levels in human breast tumours. British Fournal of Cancer $\mathbf{5 8}$ 600-605.

Hodges LG, Cook JD, Lobenhofer EK, Li L, Bennett L, Bushel PR, Aldaz CM, Afshari CA \& Walker CL 2003 Tamoxifen functions as a molecular agonist inducing cell cycle-associated genes in breast cancer cells. Molecular Cancer Research 1 300-311.

Huguet EL, McMahon JA, McMahon AP, Bicknell R \& Harris AL 1994 Differential expression of human Wnt genes 2, 3, 4, and 7B in human breast cell lines and normal and disease states of human breast tissue. Cancer Research 54 2615-2621.

Inoue A, Yoshida N, Omoto Y, Oguchi S, Yamori T, Kiyama R \& Hayashi S 2002 Development of cDNA microarray for expression profiling of estrogen-responsive genes. Fournal of Molecular Endocrinology 29 175-192.

Jakowlew SB, Breathnach R, Jeltsch JM, Masiakowski P \& Chambon P 1984 Sequence of the pS2 mRNA induced by estrogen in the human breast cancer cell line MCF-7. Nucleic Acids Research 12 2861-2878.

Jorgensen M, Hummel R, Bevort M, Andersson AM, Skakkebaek NE \& Leffers H 1998 Detection of oestrogenic chemicals by assaying the expression level of oestrogen regulated genes. Acta Pathologica, Microbiologica et Immunologica Scandanavia 106 245-251.

Katoh M 2001 Differential regulation of WNT2 and WNT2B expression in human cancer. International Fournal of Molecular Medicine 8 657-660.

Klein-Hitpass L, Ryffel GU, Heitlinger E \& Cato AC 1988 A 13 bp palindrome is a functional estrogen responsive element and interacts specifically with estrogen receptor. Nucleic Acids Research 16 647-663.

Konig J, Nies AT, Cui Y, Leier I \& Keppler D 1999 Conjugate export pumps of the multidrug resistance protein (MRP) family: localization, substrate specificity, and MRP2-mediated drug resistance. Biochimica et Biophysica Acta 1461 377-394.

Kousteni S, Bellido T, Plotkin LI, O'Brien CA, Bodenner DL, Han L, Han K, DiGregorio GB, Katzenellenbogen JA, Katzenellenbogen BS, Roberson PK, Weinstein RS, Jilka RL \& Manolagas SC 2001 Nongenotropic, sex-nonspecific signaling through the estrogen or androgen receptors: dissociation from transcriptional activity. Cell $\mathbf{1 0 4}$ 719-730.

Krege JH, Hodgin JB, Couse JF, Enmark E, Warner M, Mahler JF, Sar M, Korach KS, Gustafsson JA \& Smithies O 1998 Generation and reproductive phenotypes of mice lacking estrogen receptor beta. PNAS 95 15677-15682.

Kuiper GG, Enmark E, Pelto-Huikko M, Nilsson S \& Gustafsson JA 1996 Cloning of a novel receptor expressed in rat prostate and ovary. PNAS 93 5925-5930.

McKenna NJ, Xu J, Nawaz Z, Tsai SY, Tsai MJ \& O'Malley BW 1999 Nuclear receptor coactivators: multiple enzymes, multiple 
complexes, multiple functions. Fournal of Steroid Biochemistry and Molecular Biology 69 3-12.

Martinerie C, Gicquel C, Louvel A, Laurent M, Schofield PN \& Le Bouc Y 2001 Altered expression of novH is associated with human adrenocortical tumorigenesis. Fournal of Clinical Endocrinology and Metabolism 86 3929-3940.

Martinez-Lacaci I, Saceda M, Plowman GD, Johnson GR, Normanno N, Salomon DS \& Dickson RB 1995 Estrogen and phorbol esters regulate amphiregulin expression by two separate mechanisms in human breast cancer cell lines. Endocrinology 136 3983-3992.

Mauro L, Salerno M, Panno ML, Bellizzi D, Sisci D, Miglietta A, Surmacz E \& Ando S 2001 Estradiol increases IRS-1 gene expression and insulin signaling in breast cancer cells. Biochemical and Biophysical Research Communications 288 685-689.

Nonet GH, Stampfer MR, Chin K, Gray JW, Collins CC \& Yaswen P 2001 The ZNF217 gene amplified in breast cancers promotes immortalization of human mammary epithelial cells. Cancer Research 61 1250-1254.

Ogawa S, Eng V, Taylor J, Lubahn DB, Korach KS \& Pfaff DW 1998 Roles of estrogen receptor-alpha gene expression in reproduction-related behaviors in female mice. Endocrinology 139 $5070-5081$.

Pichon MF, Broet P, Magdelenat H, Delarue JC, Spyratos F, Basuyau JP, Saez S, Rallet A, Courriere P, Millon R \& Asselain B 1996 Prognostic value of steroid receptors after long-term follow-up of 2257 operable breast cancers. British Fournal of Cancer 73 1545-1551.

Pike MC, Spicer DV, Dahmoush L \& Press MF 1993 Estrogens, progestogens, normal breast cell proliferation, and breast cancer risk. Epidemiologic Reviews 15 17-35.

Pink JJ \& Jordan VC 1996 Models of estrogen receptor regulation by estrogens and antiestrogens in breast cancer cell lines. Cancer Research 56 2321-2330.

Pons M, Gagne D, Nicolas JC \& Mehtali M 1990 A new cellular model of response to estrogens: a bioluminescent test to characterize (anti) estrogen molecules. Biotechniques 9 450-459.

Prall OW, Sarcevic B, Musgrove EA, Watts CK \& Sutherland RL 1997 Estrogen-induced activation of Cdk4 and Cdk2 during G1-S phase progression is accompanied by increased cyclin Dl expression and decreased cyclin-dependent kinase inhibitor association with cyclin E-Cdk2. Journal of Biological Chemistry 272 10882-10894.
Qin C, Singh P \& Safe S 1999 Transcriptional activation of insulin-like growth factor-binding protein- 4 by 17 beta-estradiol in MCF-7 cells: role of estrogen receptor-Spl complexes. Endocrinology 140 2501-2508.

Raff JW 2002 Centrosomes and cancer: lessons from a TACC. Trends in Cell Biology 12 222-225.

Rajeevan MS, Vernon SD, Taysavang N \& Unger ER 2001 Validation of array-based gene expression profiles by real-time (kinetic) RT-PCR. Fournal of Molecular Diagnostics 3 26-31.

Russell KS \& Hung MC 1992 Transcriptional repression of the neu protooncogene by estrogen stimulated estrogen receptor. Cancer Research $526624-6629$.

Safe S 2001 Transcriptional activation of genes by 17 beta-estradiol through estrogen receptor-Spl interactions. Vitamins and Hormones 62 231-252.

Scholz G, Martinerie C, Perbal B \& Hanafusa H 1996 Transcriptional down regulation of the nov proto-oncogene in fibroblasts transformed by p60 v-src. Molecular and Cellular Biology 16 481-486.

Shang Y \& Brown M 2002 Molecular determinants for the tissue specificity of SERMs. Science 295 2465-2468.

Soulez M \& Parker MG 2001 Identification of novel oestrogen receptor target genes in human ZR75-1 breast cancer cells by expression profiling. Fournal of Molecular Endocrinology 27 259-274.

Webb P, Nguyen P, Valentine C, Lopez GN, Kwok GR, McInerney E, Katzenellenbogen BS, Enmark E, Gustafsson JA, Nilsson S \& Kushner PJ 1999 The estrogen receptor enhances AP-1 activity by two distinct mechanisms with different requirements for receptor transactivation functions. Molecular Endocrinology 13 $1672-1685$.

Zelinski DP, Zantek ND, Stewart JC, Irizarry AR \& Kinch MS 2001 EphA2 overexpression causes tumorigenesis of mammary epithelial cells. Cancer Research 61 2301-2306.

Zelinski DP, Zantek ND, Walker-Daniels J, Peters MA, Taparowsky EJ \& Kinch MS 2002 Estrogen and Myc negatively regulate expression of the EphA2 tyrosine kinase. Fournal of Cellular Biochemistry 85 714-720.

Received in final form 26 November 2003 Accepted 15 Decmber 2003 